\title{
COMPETITIVENESS OF CROATIA: THE ROLE OF BUSINESS ENVIRONMENT
}

\section{Valentina Vučković *}

\begin{abstract}
The purpose of this paper is to analyze the Croatian business environment quality, with the primary goal of identifying reforms needed for achieving the full potential of the private sector in stimulating national competitiveness. Using the specific competitiveness indictors - Global Competitiveness Index, Worldwide Governance Indicators and Doing Business - it is shown that the overall business environment in Croatia must be profoundly improved in order to become a driver of country's competitiveness growth. Not only that for a decade Croatia stagnates on the competitiveness scales, but it also lags behind comparator countries selected for the purpose of the analysis in this paper (Romania, Bulgaria, Hungary and Poland). As the biggest opportunities for increasing competitiveness in Croatia are found to be in the tax system and property registration area, as well as in the area of contract enforcing which would involve a more systemic judicial reform.
\end{abstract}

KEYWORDS: competitiveness, business environment, Croatia, reforms

\section{INTRODUCTION}

It is often stressed that long-term benefits in terms of increased competitiveness can best be achieved by deepening the reforms that encourage a more attractive and competitive business environment. Some of the repeatedly proposed measures include reforms for improving conditions for the entry of new firms, improving the supply response of existing firms through privatization or foreign direct investment (FDI), improving labor productivity through im-

\footnotetext{
Assistant Professor at Department of Economic Theory, Faculty of Economics and Business, University of Zagreb; vvuckovic@efzg.hr
} 
proved education and training, and ensuring unit labor costs are in line with competitors and export market conditions ${ }^{1}$.

In the context of the global economic crisis that began in the fall of 2008, the European Union (EU) economy has shown a large number of structural deficiencies and further reaffirmed the need for reforms that would boost attractive and competitive business environment in a politically and socially acceptable way. Specifically, the "Europe 2020" strategy encompasses two flagship initiatives related to the business environment. These are the "An Integrated Industrial Policy for the Globalization Era" and the "An Agenda for new skills and jobs: A European contribution towards full employment"2. Both initiatives envisage actions at EU level, but also the increased efforts of Member States at national level in order to improve the business environment. By joining the EU in 2013, Croatia has become part of a dynamic and open market that promotes the private sector development, whereas the small and medium-sized entrepreneurship has an important role in this respect, especially in the wider context of increasing national competitiveness.

The purpose of this paper is to analyze the Croatian business environment quality, with the primary goal of identifying reforms needed for achieving the full potential of the private sector in stimulating national competitiveness. The paper is structured as follows. After the introduction, in the second part of the paper we bring the discussion on the business environment as one of the factor of competitiveness. In third section, Croatia is compared to selected comparator EU members, along with the potential impact that various elements of business environment could have on its national competitiveness. The fourth section brings the overview of business environment reforms implemented so far. Finally, in the concluding remarks, specific business environment reforms which could further increase Croatian position on the competitiveness scales will be identified.

\section{BUSINESS ENVIRONMENT AS A DRIVER OF COMPETITIVENESS}

The notion of competitiveness has become one of the most analyzed and powerful concepts of modern economic thought whose definition is constantly changing ${ }^{3}$.

\footnotetext{
1 Bartlett, W.: Economic Development in the European Super-periphery: Evidence from the Western Balkans, Economic Annals, 54 (181), 2009, p.29.

2 European Commission: Europe 2020 - A European strategy for smart, sustainable and inclusive growth, Available at: http://ec.europa.eu/eu2020/pdf/COMPLET\%20EN\%20BARRO SO\%20\%20\%20007\%20-\%20Europe\%202020\%20-\%20EN\%20version.pdf (10 June, 2018).

3 Garelli, S.: Competitiveness of Nations: The Fundamentals, in IMD World Competitiveness Yearbook, Lausanne, 2004., pp. 730-742.
} 
Despite a large number of international and domestic studies ${ }^{4}$, there still does not exist a generally accepted theoretical framework for the analysis of the competitiveness. To be precise, it is a multidimensional and complex phenomenon the interpretation of which changes depending on the specific dimensions and levels at which it is analyzed. A specific dimension of competitiveness that is being discussed in this paper is the business environment quality that is considered to be the basis for developing a modern market economy and improved competitiveness and innovation ${ }^{5}$. The term considers the extent to which government policies, laws and regulations define the rules of the game for businesses and immediately affect (positively or negatively) the businesses through direct and indirect costs of compliance ${ }^{6}$. As being a multi-dimensional, there is a variety of terms used in the literature, such as the investment climate, entrepreneurial climate, the business environment, regulatory business environment etc., all of which are often used as synonyms.

It has been shown that the competitiveness of companies, regions and countries increasingly depends on intentional actions of key actors (the so-called man-made competitive advantages), interaction between a large number of private and public agents and the existence of highly specialized and diversified institutions ${ }^{7}$. Thus, along with the significance of the traditional factors, i.e. role of macroeconomic policies, there is a growing consensus that business regulations are those that promote business activity. However, even though the development of entrepreneurship per se is not a guarantee of increasing the added value, the friendly business environment could boost the business dynamics and the development of fast-growing firms that have a positive impact on economic performance. Thus, by improving the countries business environment, policy makers can open up new opportunities for existing and potential entrepreneurs, indirectly resulting in increased competitiveness.

Although the per capita GDP (along with the labor productivity) is the most commonly used individual competitiveness measure, there is a growing num-

$4 \quad$ Ibid.; Biggeri, L.: New challenges in the measurement of competitiveness in economic globalisation, Document I/8, Budapest, 2007; Dragičević, M.: Konkurentnost: Projekt za Hrvatsku, Školska knjiga, Zagreb, 2012; Porter, M: The Competitive Advantages of Nations, London and Basingstoke, Macmillan, 1990, etc.

5 Klapper, L. F., Love, I.: The Impact of Business Environment Reforms on New Firm Registration, World Bank Policy Research Working Paper No. 5493., 2010. Available at http:// siteresources.worldbank.org/INTFR/Resources/Klapper_Love_Feb14_12.pdf (10 June, 2018)

6 UNIDO: Creating an Enabling Environment for Private Sector Development in sub-Saharan Africa, United Nations Industrial Development Organization (UNIDO) and the Deutsche Gesellschaft für Technische Zusammenarbeit (GTZ), Vienna, 2008; 16. White, S., Fortune, P.: Review of DFID Activities in the Enabling Environment, Investment, Competition and Enabling Environment Team Policy Division (final report), 2004.

7 UNIDO, ibid., p. 9. 
ber of factors affecting the competitiveness of countries. As a result, different indices that cover this wide range of factors have been developed. Although the macroeconomic profile of a country is presented by using macroeconomic indicators, these cannot say much about the competitiveness dynamics nor about the obstacles to its growth ${ }^{8}$.

The most commonly used index for assessing the international competitiveness of countries is the Global Competitiveness Index (GCI) developed by the World Economic Forum ${ }^{9}$. The institutional indicators such as the Human Development Index, the Corruption Perception Index, the European Innovation Scoreboard and Worldwide Governance Indicators also became particularly relevant after the concept of competitiveness became a political issue in the $1980 \mathrm{~s}^{10}$. On the other side, the Doing Business is the most well-known indicator of business environment quality and reforms, and is in more detail described in the following section.

It is worth mentioning that all of the above indicators are faced with the same advantages and disadvantages which are highlighted for composite indices in general ${ }^{11}$. But, despite critics, composite indices are very often used in research when concepts that cannot be described by only one indicator are to be measured. National competitiveness is just an example of such a concept. However, due to the weaknesses of the indices that combine quantitative and qualitative data, a certain precaution is required when interpreting the results that are obtained based on these data, especially by policy makers.

\section{COMPETITIVENSS ANALYSIS OF THE CROATIAN ECONOMY: PUTTING THE BUSINESS ENVIRONMENT UNDER THE SPOTLIGHT}

Despite the significant progress achieved over the past, a large number of EU members are still faced with serious business environment issues, especially

\footnotetext{
8 Dragičević, op. cit. (fn. 4), p. 38-39.

9 According to WEF, competitiveness is a set of institutions, policies and pillars that determine the level of productivity of a country which in turn determines the level of prosperity that an economy can achieve. The methodology is based on an analysis of 12 pillars of competitiveness: institutions, infrastructure, macroeconomic environment, health and primary education, higher education and training, goods market efficiency, labour market efficiency, financial market development, technological readiness, market size, business sophistication, and innovation, https://www.weforum.org/ (14 June, 2018).

10 Kantola, A.: Transforming political imaginaries: the uses of competitiveness, Working Paper 3, 2006.

11 See OECD (2008). Handbook on Constructing Composite Indicators: Methodology and User Guide, OECD Statistics Working Paper, STD/DOC (2005)3.
} 
when it comes to small and medium-sized enterprises (SMEs). Despite the existence of a Single Market and reforms implemented so far, the business environment differs considerably between individual EU member states ${ }^{12}$. When countries become members of the EU, they no longer take advantage of the use of traditional economic policy instruments (such as quotas, customs, exchange rates, etc.), but what remains are fiscal policy instruments and structural reforms. The same goes for Croatia as the newest, $28^{\text {th }} \mathrm{EU}$ member state since 2013. In the following lines, competitiveness profile of Croatia is presented, with special focus on business environment dimension, with the main goal of highlighting the areas with the largest reform potential.

For a number of years, Croatia has faced deeply rooted issues in the field of competitiveness. Since 2002, the first year that has been included in the Global Competitiveness Index (GCI) of the World Economic Forum (WEF), Croatia has experienced a constant decline in competitiveness, with real growth on the competitiveness scale achieved only in the period from 2005 to 2007. According to the latest "Global Competitiveness report 2017 - 2018"13 Croatia is ranked $74^{\text {th }}$ (out of 137 countries), which represents a stagnation relative to the previous year. Croatia recorded a significant deterioration in the following pillars: institutions, which fell by 13 places; higher education and training, which fell by 11 places; and efficiency of the labor market, which fell by 7 places. Areas where Croatia scored growth on the competitiveness scale are found in the pillar of macroeconomic environment (improvement by 24 places); health and primary education (improvement by 22 places); technological readiness (improvement by 4 places) and market size (improvement by 1 place). These results confirm that Croatia is constantly faced with excessive limitations from the aspect of policies dealing with the degree of state control over the economy and the obstacles to entrepreneurship ${ }^{14}$.

If we look at the specific values of GCI, although the index values started to increase in 2015, we can see that Croatia is lagging behind all of the selected comparator countries (Bulgaria, Hungary, Poland and Romania ${ }^{15}$ ) (Figure 1).

\footnotetext{
12 Galli, G., Pelkmans, J. (eds.), Regulatory Reform and Competitiveness in Europe, 1: Horizontal issues, Cheltnham, 2000., p.7.

13 See https://www.weforum.org/reports/the-global-competitiveness-report-2017-2018.

14 World Bank: Izvješće o konvergenciji Hrvatske s EU: ostvarivanje i održavanje viših stopa gospodarskog rasta, 2009.

15 These EU countries are selected as being grouped with Croatia in the same regional group within the GCI, the group of Emerging and Developing Europe.
} 
Figure 1. Global Competitiveness Index: Croatia vs. comparator countries, 2007. - 2017. Notes: Index takes values from 1 to 7. Source: Authors compilation based on WEF data $(2007-2017)^{16}$

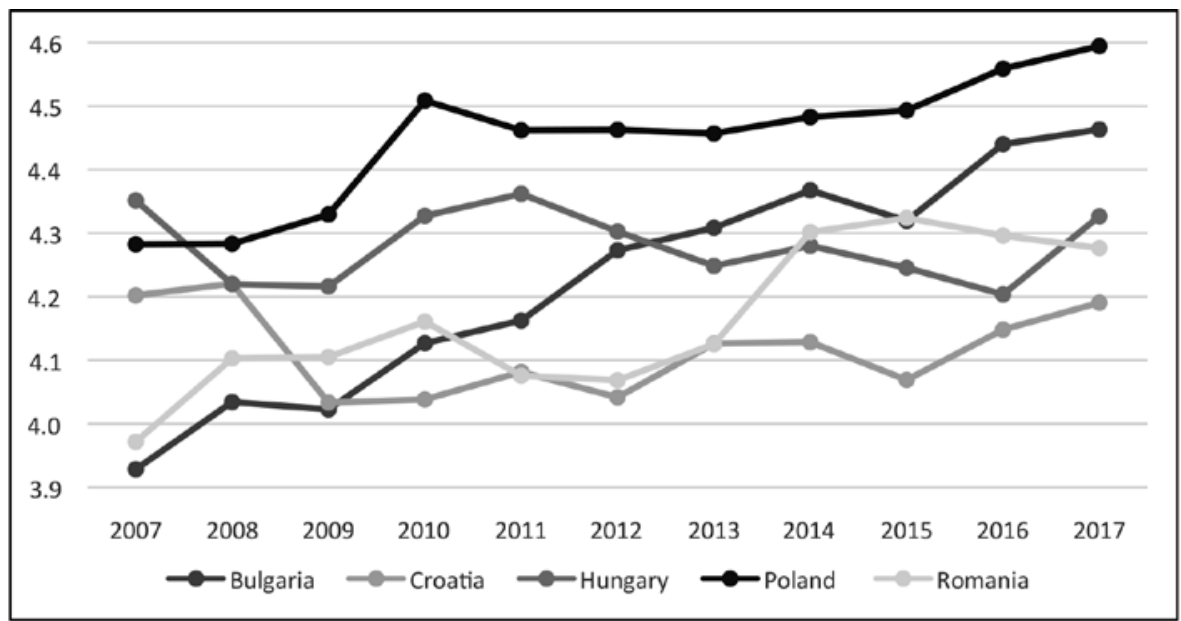

If we analyze the Croatian rank (nominal and real), as well as the linear trend of the index values for the 10-year period (Figure 2), it is obvious that Croatia is stagnating on the competitiveness scale, i.e. that other countries improve their competitiveness much faster.

Figure 2. Competitiveness ranks and GCI for Croatia (2007-2017). Source: Authors compilation based on WEF data $(2007-2017)^{17}$

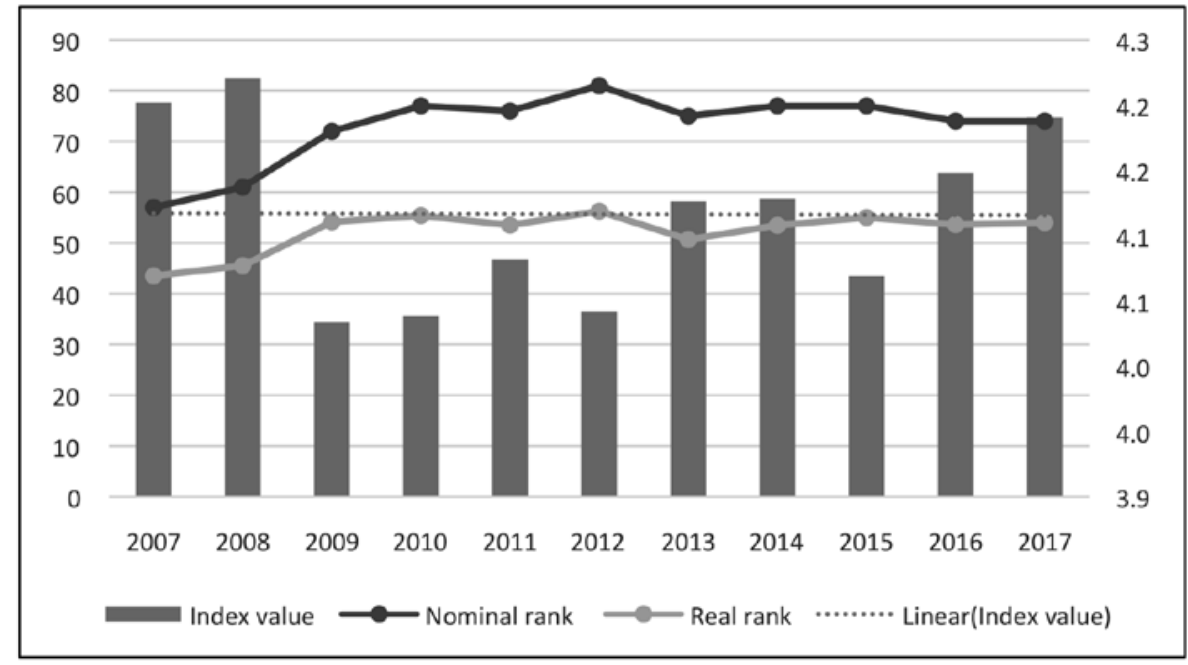

See https://www.weforum.org/reports/the-global-competitiveness-report-2017-2018.

17 See https://www.weforum.org/reports/the-global-competitiveness-report-2017-2018. 
The situation becomes even worse if we analyze the position of Croatia from the aspect of specific development stages: the development phase based on the basic requirements; the phase based on the efficiency enhancers and the phase based on innovation and sophistication factors, we can conclude that Croatia's competitiveness as a country that is on a path of transition from second to third phase is not satisfactory. Table 1 gives an overview of the ranks of the individual pillars of Croatia's competitiveness according to the mentioned phases published in the latest "Global Competitiveness Report 2017-2018", as well as the change in the rank compared to the year 2007. The data show that the lowest value of the GCI is recorded at the institutions and innovation pillar, which are, along with the labor and goods market efficiency, the worst ranked pillars.

Table 1. Competitiveness ranks by development phases $(2006$ - 2013). Notes: $\uparrow$ represents the improvement in the competitiveness scale (smaller rank), ! represents deterioration on competitiveness scale (higher rank). Source: Authors compilation based on WEF data $(2017)^{18}$.

\begin{tabular}{|l|c|c|c|}
\hline & $\begin{array}{c}\text { 2017 RANK } \\
\text { (out of 137) }\end{array}$ & $\begin{array}{c}\text { SCORE } \\
\text { (1-7) }\end{array}$ & 2017/2007 \\
\hline 1. BASIC REQUIREMENTS & 58 & 4,8 & $105 \downarrow$ \\
\hline Institutions & 102 & 3,5 & $150 \downarrow$ \\
\hline Infrastructure & 48 & 4,6 & $87 \uparrow$ \\
\hline Macroeconomic environment & 60 & 4,8 & $79 \uparrow$ \\
\hline Health and primary education & 44 & 6,1 & $96 \uparrow$ \\
\hline 2. EFFICIENCY ENHANCERS & 69 & 4,1 & $108 \downarrow$ \\
\hline Higher education and training & 60 & 4,5 & $125 \downarrow$ \\
\hline Goods market efficiency & 99 & 4 & $133 \downarrow$ \\
\hline Labor market efficiency & 107 & 3,8 & $183 \downarrow$ \\
\hline Financial market development & 95 & 3,6 & $134 \downarrow$ \\
\hline Technological readiness & 43 & 5 & $84 \downarrow$ \\
\hline Market size & 77 & 3,6 & $115 \downarrow$ \\
\hline $\begin{array}{l}\text { 3. INNOVATION AND } \\
\text { SOPHISTICATION FACTORS }\end{array}$ & 99 & 3,4 & $153 \downarrow$ \\
\hline Business sophistication & 82 & 3,8 & $109 \downarrow$ \\
\hline Innovation & 106 & 2,9 & $203 \downarrow$ \\
\hline
\end{tabular}

18 See https://www.weforum.org/reports/the-global-competitiveness-report-2017-2018. 
If we combine described trends with factors that are identified as most problematic for doing business in Croatia (Figure 3, also published within the same report), i.e. inefficient government bureaucracy, policy instability, tax regulations, corruption and tax rates, we again can conclude that there is a distinct problem in Croatia which stems from policies with high degree of state control over the economy thus resulting in high barriers to entrepreneurship development.

Figure 3. Most problematic factors for doing business in Croatia. Source: WEF (2017), p.98. ${ }^{19}$

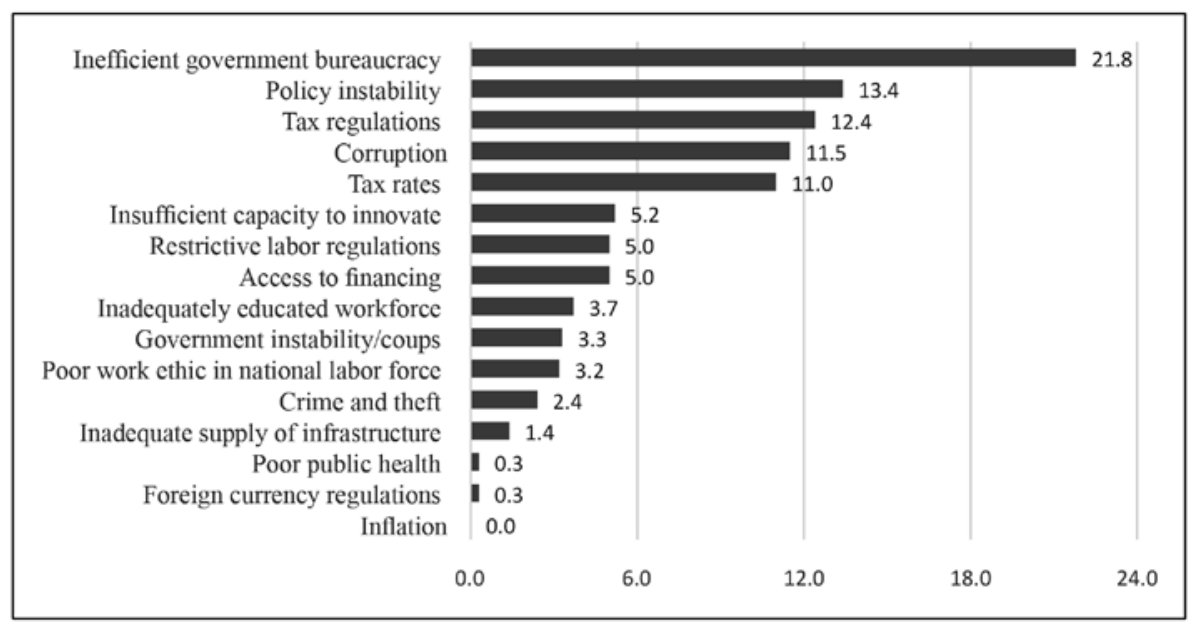

Therefore, it is necessary to analyze the competitiveness of Croatia also from the aspects of Worldwide Governance Indicators ${ }^{20}$ which are relevant because governments in individual countries play a major role in determining the development paths of their economies ${ }^{21}$, and to see under which out of six dimensions of governance Croatia performs the worst. The data presented in the Figure 4 confirm that the Croatia is faced with significant obstacles in the business environment. Precisely, the dimension of governance within which Croatia performs worst relative to selected comparator countries is the Regulatory Quality dimension which reflects the ability of the government to formulate and implement sound policies and regulations that permit and promote private sector development ${ }^{22}$.

19 See https://www.weforum.org/reports/the-global-competitiveness-report-2017-2018, p.98

20 See http://info.worldbank.org/governance/wgi/index.asp.

21 Dragičević, op. cit. (fn. 4), p. 117.

22 See http://info.worldbank.org/governance/wgi/index.aspx\#doc-intro. 
Figure 4. Worldwide Governance Indicators (2007 - 2016 average). Notes: V\&A - Voice and Accountability, Political Stability and Absence of Violence, Government Effectiveness, Regulatory Quality, Rule of Law, Control of Corruption. Source: Authors calculation based on World Bank (2018). ${ }^{23}$

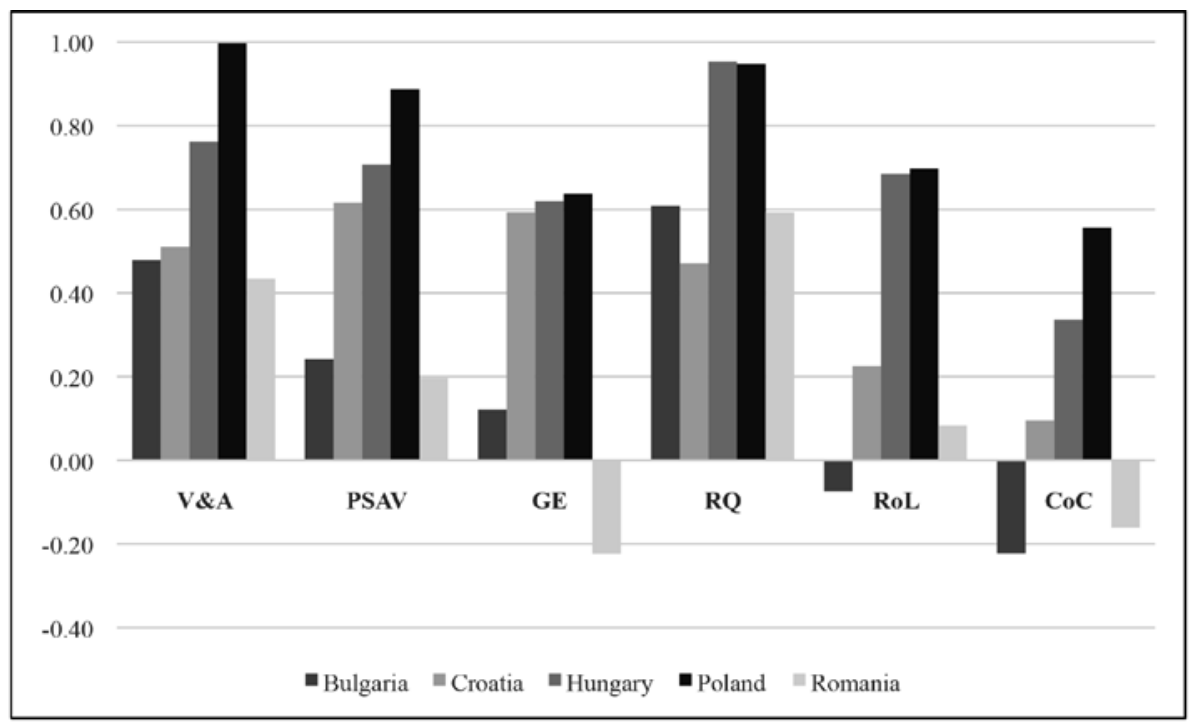

We can conclude that the analyzed indicators of competitiveness so far indicate that the business environment in Croatia is characterized by numerous difficulties and barriers, with high levels of government regulation, inefficiency of the tax system and restrictive labor legislation being only some of the many obstacles that point out to the need for reforms that would improve the Croatian position on international competitiveness rankings.

We proceed by the analysis of the business environment quality based on the one of the most often used measures of business environment. This is the Doing Business series of reports published by World Bank that evaluate economies based on how business friendly their regulatory systems are using the distance to frontier (DTF) score and the ease of doing business ranking. A methodology was developed by Djankov et al. (2002), and since 2003, the World Bank's Doing Business report quantifies the business environment quality in more than 170 countries (this number is now at 190 countries). Although data regarding the quality of business environment are also available from alternative sources such as the Heritage Foundation's Index of Economic Freedom, which is also commonly used in this area of research, the World Bank Doing Business database has two main advantages. Apart from the fact that

23 See http://info.worldbank.org/governance/wgi/index.aspx\#doc-intro. 
the indicators are based on specific implemented reforms, taking into account this specific set of reforms diminishes the problem of reverse causality with econometric analyses ${ }^{24}$.

According to the latest World Bank report, "Doing Business 2018"25, indicators for Croatia indicate the constant presence of a large number of bottlenecks in a business environment that hamper the private sector development. This is evident if we look at the ranking of Croatia according to the Ease of Doing Business, relative to selected comparator countries where Croatia records the lowest rank (Figure 5). Also, along with the rankings of Ease of Doing Business, the figure shows the distance to frontier (DTF) indicator. The main disadvantage of the countries' ranking according to the Ease of Doing Business, is reflected in the fact that it measures the performance of a particular country relative to all others. Thus, given that it does not provide information on the dynamics of business environment quality, nor the information about the gap between countries at a certain point in time which is particularly relevant in the analysis of business environment quality by individual countries (and not groups of countries), an additional indicator - distance to frontier (DTF) was developed. DTF measure shows the distance of each economy to the "frontier," which represents the best performance observed on each of the indicators across all economies in the Doing Business sample since 2005. An economy's distance to frontier is reported on a scale from 0 to 100 , where 0 represents the lowest performance and 100 represent the frontier ${ }^{26}$.

Among 190 countries encompassed by this year Report, Croatia is ranked $51^{\text {st }}$, recording deteriorated ranking compared to the last year (rank 43 out of 190). On the other side, it has recorded a positive shift of +0.05 in DTF, which indicates a slight improvement in business conditions. Despite this improvement, Croatian DTF is the lowest relative to comparator EU countries, thus confirming the poor performance of business environment as one of the competitiveness factor.

${ }^{24}$ Haidar, J. I.: The impact of business regulatory reforms on economic growth, Journal of The Japanese and International Economies. 26 (3), 2012.

25 World Bank: Doing Business 2018, 2017, Available at: http://www.doingbusiness.org/reports/global-reports/doing-business-2018 (14 June, 2018).

26 Ibid. 
Figure 5. Ease of Doing Business rank and DTF. Source: Authors compilation based on World Bank (2017) ${ }^{27}$.

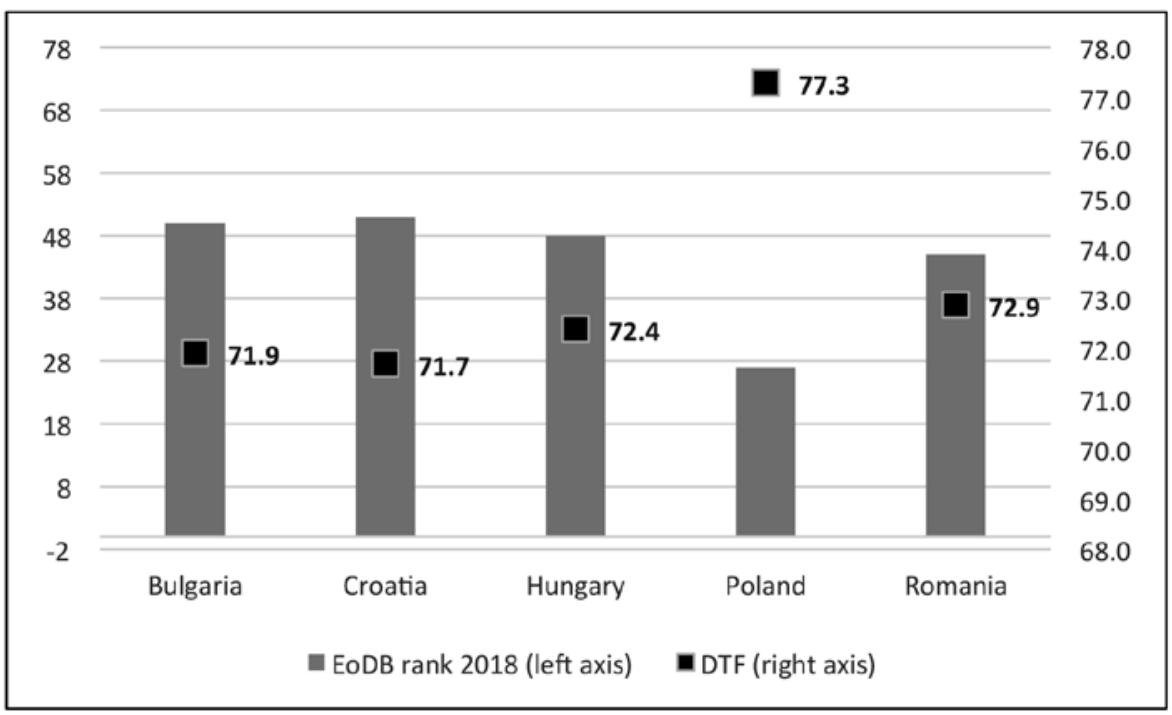

Given that the literature often points out that (despite the problems that characterize it), the private sector in Croatia has the potential to compete in the EU market, it is necessary to investigate in which areas (i.e. sub-indexes) that make the Ease of Doing Business Croatia records the worst results. This could then contribute to the identification of specific areas for potential improvements.

Below is an analysis of the quality of business environment with regard to two categories of indicators covered by the Doing Business database: those related to the strength of legal institutions (getting credit, minority investors protection, enforcing contracts, resolving insolvency) and those related to the complexity and cost of regulatory processes (starting a business, obtaining construction permits, getting electricity, registering property, paying taxes and trading across borders) (Figure 6).

27 Ibid. 
Figure 6. Broader categories of the strength of legal institutions and of the complexity and cost of regulatory processes. Source: Authors calculation based on World Bank (2017) ${ }^{28}$.

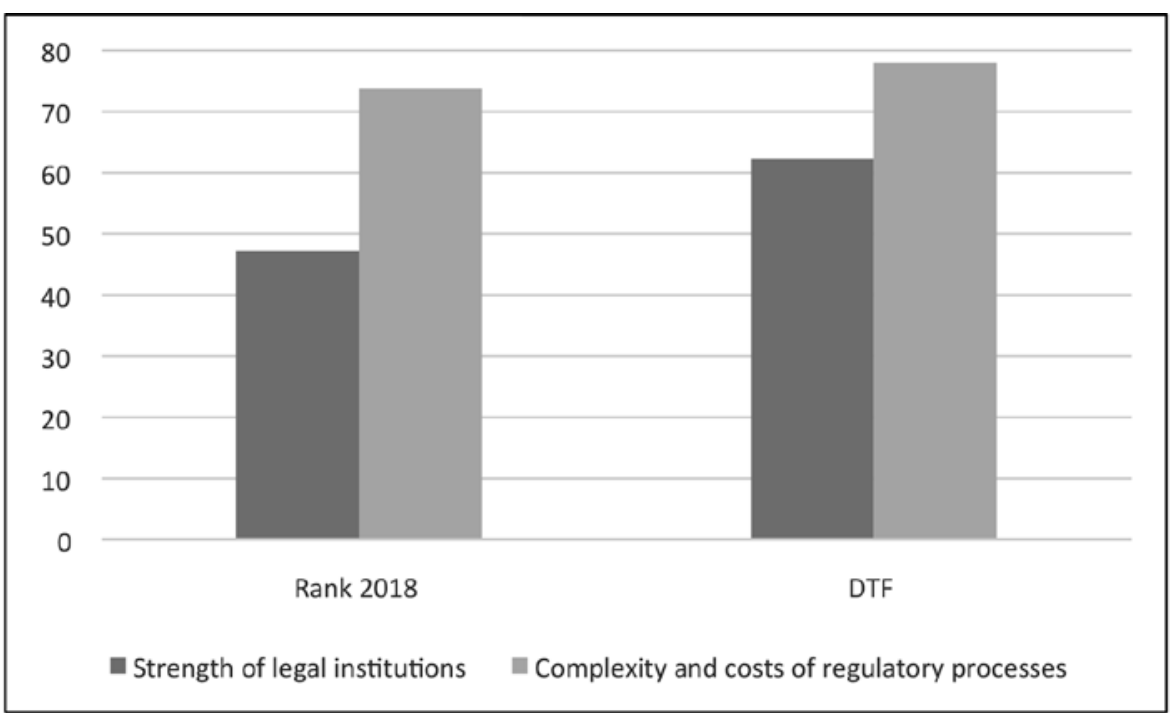

Based on the comparison of the indicators organized in these two groups, we can conclude that, Croatia performs worse from the aspect of indicators in the first group, i.e. indicators related to the strength of legal institutions. These trends imply that further reforms are needed in the business environment to improve Croatia's position on the international competitiveness scale.

\section{WHAT HAS BEEN DONE SO FAR IN CROATIA IN ORDER TO IMPROVE BUSINESS ENVIRONMENT?}

Below is an overview of the current dynamics of the implementation of business environment reforms in Croatia (Table 22). The + sign implies that implemented Doing Business reform makes it easier to do business, while - sign implies that Doing Business reform makes it more difficult to do business.

28 Ibid. 

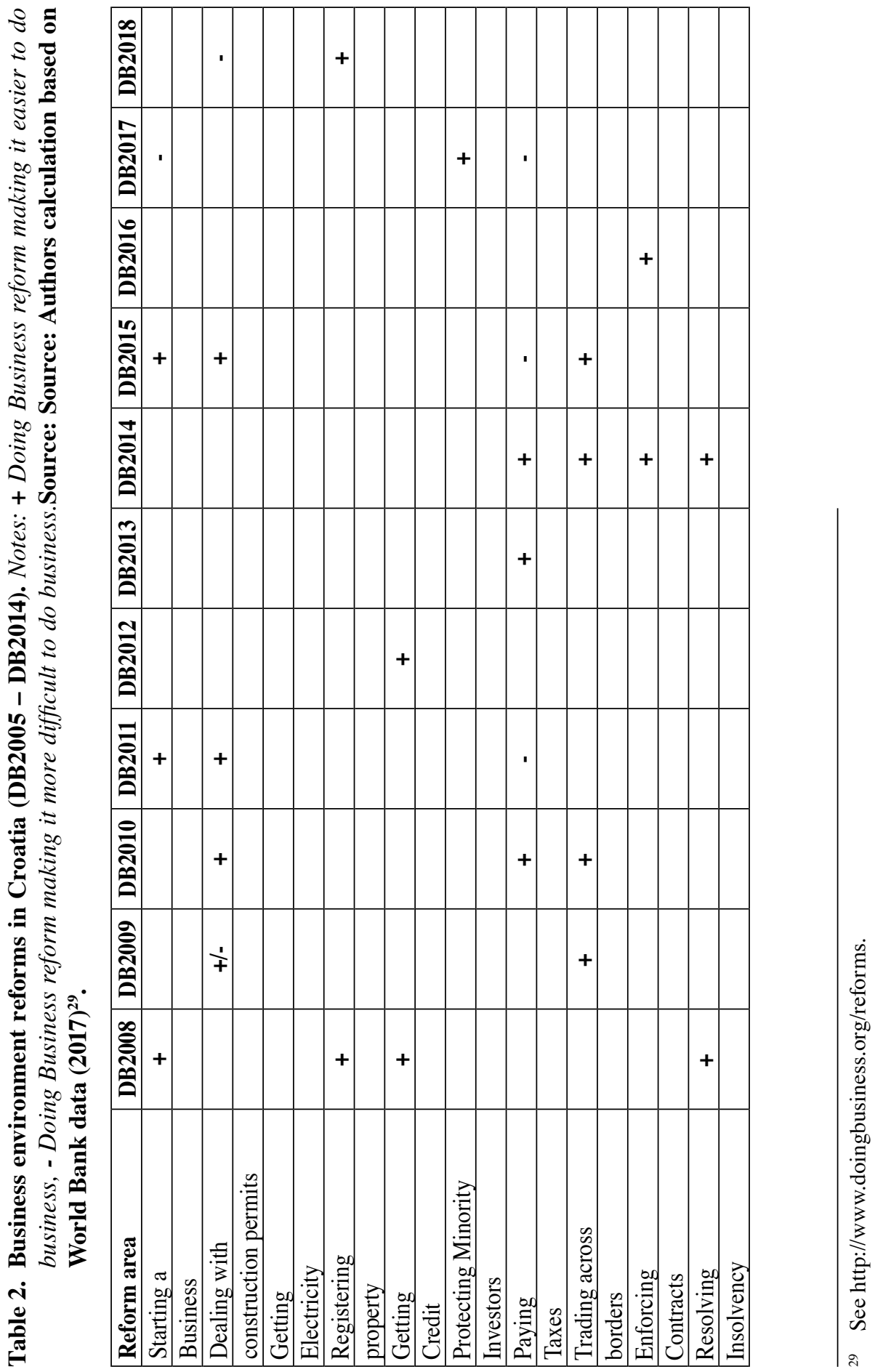
In the 2006-2007 period that is encompassed by the Doing Business 2008 report (World Bank, 2008), reforms were implemented in five areas. These are the reforms in the area of starting a business, registering property, getting credit, and resolving insolvency. It is interesting to note that within this report, Croatia was ranked among the best reformer countries. This period was marked with several novelties: the HITRO.hr (one-stop shop for newly established companies) project that started in 2005, the negotiations process for EU membership, regulator guillotine project called Hitrorez also began in 2006, as well as monitoring the implementation of the European Charter for Small Enterprises through the SMEs Policy Index. However, after this period, as evident from the table above, there has been a decrease in the number of reforms implemented until the 2012-2013 period covered by the 2014 Report.

In this period, reforms were implemented in the area of paying taxes, trading across borders, enforcing contracts and resolving insolvency. Also, Croatia facilitated business start-up making possible to establish a simple limited liability company through simplified procedures and by lower minimum capital requirements. Paying taxes was simplified through introducing an electronic system for social security contributions and by reducing the rates for the forest and Chamber of Commerce contributions. Other reforms included improving the physical and information system infrastructure at the port of Rijeka, harmonization of EU trading procedures and, streamlining litigation proceedings and transferring certain enforcement procedures from the courts to state agencies and introducing an expedited out-of-court restructuring procedure.

If we look at individual reform areas, we can see that Croatia has implemented the largest number of reforms within Trading Across Borders and Paying Taxes area, although not all were the reforms making it more easier to do business. On the other hand, the smallest number of reforms was implemented in the areas of Registering Property, Getting Credit, Protecting Minority Investors, Enforcing Contracts and Resolving Insolvency.

Based on the descriptive analysis of main competitiveness and business environment indicators for Croatia, we can conclude that the biggest opportunities for increasing competitiveness are in the tax system and property registration area, as well as in the area of contract enforcing which involve more systemic judicial reform. Further, as being one of the determinants of costs and efficiency of regulatory processes, these areas should be given a priority when designing the reform programs, and instead of reducing one-off costs of business formalization, the goal should be to reduce the transaction costs. It has been shown that in countries that were more burdened by start-up regulations, there will not be an observed increase in business activity after reducing such barriers. Thus, reducing barriers to entry does not solve the structural pro- 
blems of the majority of informal enterprises so the strategies to increase competitiveness based on the removal of only such barriers should be revised ${ }^{30}$.

However, the real challenge is to define appropriate levels of regulation rather than abolishing them in total. Since the development of favorable business environment is a complex process where each intervention could involve substantial risks of inefficiency or political capture, understanding the political context of it is crucial for the effective involvement of all stakeholders in the political dialogue that promotes changes ${ }^{31}$. Thus, as being a political process, for the success of any reform (including the business environment reforms), it is necessary to consolidate all the actors involved in it. Since these are all the reforms the implementation of which could take years, it is no surprise that they have been constantly up in the air.

All Doing Business reports point out that business environment reforms are crucial for growth and competitiveness, but there is less information about how they can be implemented and it is worth noting that there could be some traps in blindly following the recommendations as a general rule without taking into consideration specific circumstances in individual countries. In this line of reasoning, problems that arise in implementing business environment reforms are often underestimated ${ }^{32}$. Often, countries led by the aim of improving their rankings on the Doing Business rankings too quickly "fussed" into reforms that simplified business formalization while on the other hand introduced additional procedures, costs and even new organizations, which only further increased the bureaucratic apparatus of the state ${ }^{33}$

\section{CONCLUDING REMARKS}

The overall business environment in Croatia must be radically improved in order to become a driver of country's competitiveness growth. Competitiveness indicators of Croatia described in this paper could give out signals to go-

\footnotetext{
30 Van Stel, A., Storey, D., Thurik, R., The Effect of Business Regulations on Nascent and Young Business Entrepreneurship, Small Business Economics, 28, 2007, pp. 171 - 186.

31 World Bank: The Political Economy of Policy Reform: Issues and Implications for Policy Dialogue and Development Operations, Social Development Department, 2008.

32 Altenburg, T., von Drachenfels, C.: Business environment reforms: Why it is necessary to rethink priorities and strategies, Enterprise Development and Microfinance, 19 (3), 2008, pp. 191-203.

33 Arruñada, B.: Pitfalls to Avoid when Measuring Institutions: Is Doing Business Damaging Business?, Journal of Comparative Economics, 35(4), 2007., pp. 729-747; Kirkpatrick, C., Piesse, J.: Regulation for Enterprise Development and Regulatory Impact Assessment, Enterprise Development Impact Assessment Information Service (EDIAS), 2001. .
} 
vernment and the general public about the quality of business environment in Croatia, based on which various business decisions could be made. Precisely, we can conclude that the quality of business environment in Croatia is a significant deterring factor for competitiveness growth. In addition, Croatia lags behind selected comparator countries, so it is much needed in future research analyses what is behind such pattern. Potential answer can be found in the political economy factors, given the results of descriptive analysis of Worldwide Governance Indicators in this paper.

Out of two indicators described in more details in the paper, The Global Competitiveness Report of WEF is a much broader concept than Doing Business, and it includes indicators such as macroeconomic stability, human capital quality, institutions and various aspects of the private sector. Seven indicators that are utilized by the WEF stem from Doing Business reports, which make only about $6 \%$ of all indicators ${ }^{34}$. Thus, taking these two together when analyzing the competitiveness of countries through the business environment dimension, one can get a detailed insight into their economic performance. Precisely, as the biggest opportunities for increasing competitiveness in Croatia are found to be in the tax system and property registration area, as well as in the area of contract enforcing which would involve a more systemic judicial reform. But, as being a political process, for the success of business environment reforms, it is necessary to consolidate all the actors involved in it, and design the reform programs taking into consideration specific institutional and economic context.

\section{LITERATURE}

1. Altenburg, T., von Drachenfels, C.: Business environment reforms: Why it is necessary to rethink priorities and strategies, Enterprise Development and Microfinance, 19 (3), 2008.

-DOI: https://doi.org/10.3362/1755-1986.2008.018

2. Arruñada, B.: Pitfalls to Avoid when Measuring Institutions: Is Doing Business Damaging Business?, Journal of Comparative Economics, 35(4), 2007.

-DOI: https://doi.org/10.1016/j.jce.2007.08.003

3. Bartlett, W.: Economic Development in the European Super-periphery: Evidence from the Western Balkans, Economic Annals, 54 (181), 2009

-DOI: https://doi.org/10.2298/EKA0981021B

34 World Bank (2012). Doing Business 2013. Smarter Regulations for Small and Medium-Size Enterprises. Washington DC: World Bank. 
4. Biggeri, L.: New challenges in the measurement of competitiveness in economic globalisation, Document I/8, Budapest, 2007.

5. Dragičević, M.: Konkurentnost: Projekt za Hrvatsku, Školska knjiga, Zagreb, 2012.

6. Galli, G., Pelkmans, J. (eds.), Regulatory Reform and Competitiveness in Europe, 1: Horizontal issues, Cheltnham, 2000.

7. Garelli, S.: Competitiveness of Nations: The Fundamentals, in IMD World Competitiveness Yearbook, Lausanne, 2004.

8. Haidar, J. I.: The impact of business regulatory reforms on economic growth, Journal of The Japanese and International Economies. 26 (3), 2012.

-DOI: https://doi.org/10.1016/j.jjie.2012.05.004

9. Kantola, A.: Transforming political imaginaries: the uses of competitiveness, Working Paper 3, 2006.

10. Kirkpatrick, C., Piesse, J.: Regulation for Enterprise Development and Regulatory Impact Assessment, Enterprise Development Impact Assessment Information Service (EDIAS), 2001.

11. Klapper, L. F., Love, I.: The Impact of Business Environment Reforms on New Firm Registration, World Bank Policy Research Working Paper No. 5493., 2010. Available at http://siteresources.worldbank.org/INTFR/Resources/Klapper_ Love_Feb14_12.pdf (10 June, 2018).

12. OECD: Handbook on Constructing Composite Indicators: Methodology and User Guide, OECD Statistics Working Paper, 2008.

13. Porter, M: The Competitive Advantages of Nations, London and Basingstoke, Macmillan, 1990.

-DOI: https://doi.org/10.1007/978-1-349-11336-1

14. UNIDO: Creating an Enabling Environment for Private Sector Development in sub-Saharan Africa, United Nations Industrial Development Organization (UNIDO) and the Deutsche Gesellschaft für Technische Zusammenarbeit (GTZ), Vienna, 2008.

15. Van Stel, A., Storey, D., Thurik, R., The Effect of Business Regulations on Nascent and Young Business Entrepreneurship. Small Business Economics, 28, 2007.

-DOI: https://doi.org/10.1007/s11187-006-9014-1

16. White, S., Fortune, P.: Review of DFID Activities in the Enabling Environment, Investment, Competition and Enabling Environment Team Policy Division (final report), 2004.

17. World Bank: The Political Economy of Policy Reform: Issues and Implications for Policy Dialogue and Development Operations. Social Development Department, 2008. 
18. WorldBank:DoingBusiness2018,2017.Availableat:http://www.doingbusiness.org/ reports/global-reports/doing-business-2018 (14 June, 2018).

\section{ONLINE SOURCES}

1. https://www.weforum.org/ (14 June, 2018).

2. http://info.worldbank.org/governance/wgi/index.asp (14 June, 2018).

3. http://info.worldbank.org/governance/wgi/index.aspx\#doc-intro (14 June, 2018).

4. http://www.doingbusiness.org/reforms (14 June, 2018).

5. http://info.worldbank.org/governance/wgi/index.asp (14 June, 2018).

6. http://info.worldbank.org/governance/wgi/index.aspx\#doc-intro (14 June, 2018.)

7. http://www.doingbusiness.org/reforms (14 June, 2018).

8. https://www.weforum.org/ (14 June, 2018).

\section{OTHER SOURCES}

1. European Commission: Europe 2020 - A European strategy for smart, sustainable and inclusive growth, Available at: http://ec.europa.eu/eu2020/pdf/COMPLET\%20EN\%20BARROSO\%20\%20\%20007\%20-\%20Europe\%202020\%20 -\%20EN\%20version.pdf (10 June, 2018).

2. WEF: The Global Competitiveness Report 2017-2018, 2017. Available at: https:// www.weforum.org/reports/the-global-competitiveness-report-2017-2018 (14 June, 2018).

3. World Bank: Izvješće o konvergenciji Hrvatske s EU: ostvarivanje i održavanje viših stopa gospodarskog rasta, 2009. 